\title{
The Potential of RICOSRE to Enhance University Students' Science Literacy in Biology
}

\author{
Susriyati Mahanal ${ }^{1 *}$, S Zubaidah $^{1}$, D Setiawan ${ }^{1}$
}

\author{
${ }^{1}$ Biology Department, Faculty of Mathematics and Sciences, PUIPT Disruptive Learning Innovation, Universitas Negeri \\ Malang, Malang, Indonesia \\ *Corresponding author. Email: susriyati.mahanal.fmipa@um.ac.id
}

\begin{abstract}
Twenty-first-century skills encompass science literacy, competencies, and character qualities. Science literacy is one of the basic literacy skills that play a significant role in modern society, where people have to deal with advanced science and technology. Science literacy can be promoted in university students through learning. RICOSRE is a learning model that can be used to develop university students' science literacy. The current study aimed to investigate the potential of RICOSRE to enhance university students' science literacy through a comprehensive study of 1) the improvement of the students' science literacy during the process of learning using RICOSRE, and 2) the effect of RICOSRE on the students' science literacy. A concurrent embedded mixed methods design was employed in this study. The students' science literacy was assessed using an essay test on Protist and a science literacy rubric. The qualitative data analysis was performed descriptively based on the results of the pretest, mid-test, and post-test, while the quantitative data analysis was carried out using the Wilcoxon's non-parametric test in a one group pretest-post-test design. The results of the study showed that 1) the students' score improved by $21.37 \%$ from the pretest to the mid-test and $13.27 \%$ from the mid-test to the post-test; 2) RICOSRE had an effect on the students' science literacy with a significance level of 0.000 $<0.05$. Based on these findings, it can be concluded that RICOSRE learning model can be applied to empower university students' science literacy.
\end{abstract}

Keywords: RICOSRE, Science Literacy.

\section{INTRODUCTION}

The shifting labor market in the 21 st century has influenced the need for developing certain skills, such as basic literacy skills and character qualities [1]. Basic literacy skills cover not only the ability to read or to work with numbers but also the ability to understand science, Information and Communication Technologies (ICT), finance, cultures, and citizenship.Science literacy is one of the skills needed in the digital era. It constitutes knowledge and understanding of scientific concepts and processes that can be used in making a decision as well as participating in cultural and civic affairs and economic productivity [2].

Science literacy can be defined as "knowledge and understanding of scientific concepts and processes that are needed in decision making, civic and cultural affairs, and economic productivity [3]. In a broader sense, science literacy covers critical review, ethics awareness, and social awareness [4], while, in general, it can refer to the reflective ability to relate scientific problems to scientific notions [5]. Science literacy can also be defined as the ability to comprehend the world of science to make a good decision in a particular situation. It mainly focuses on applying knowledge of science in daily life situations [6] and understanding scientific laws, theories, and phenomena [7]. A scientifically literate person will be able to describe, explain, and predict a natural phenomenon. Science literacy contains awareness of scientific concepts and theories as well as scientific procedures and practices conducted in scientific investigations to solve everyday problems. These skills can support individuals' active participation in society [8].

Scientifically literate means being able to ask, discover, or determine answers to curiosity based on experiences. Science and technology advancement is the most prominent characteristic of the modern world, suggesting that science literacy is required for contemporary citizenship [9]. Science literacy plays a vital role in solving a problem related to science and technology found in modern society [10]. In other words, every citizen needs to develop basic scientific knowledge to make a practical decision in life. Özdem et al.[11]studied almost a hundred published articles and found out that a literate person should be competent in understanding "... (a) basic scientific concepts, (b) science characteristics, (c) ethics for scientific research, (d) the reciprocal relationship 
between science and society, (e) the reciprocal relationship between science and humanities, and (f) the differences between science and technology."

One of the primary goals of science education is the development of students' science literacy[7]. Therefore, science learning should be provided for all students regardless of age, gender, cultural background, and others. Also, the improvement of students' understanding and skills in science is crucial [9]. Biology is a branch of science. Science literacy is a skill that corresponds with the characteristics of Biology, thus it is very useful for students. Science literacy involves asking questions about life and looking for answers using science. Biology is always associated with life investigations, building a coherent relationship between one fact and another in every aspect of life.

Research suggests that the majority of university students in Indonesia perform poorly in science literacy. This is indicated by low scores achieved by a group of students from Department of Biology at Universitas Negeri Malang in Protist tests forthree years. The students obtained average scores of 67, 71, and 67 in 2015, 2016, and 2018, respectively. The students' poor science literacy was also reflected in their scores in task completion and achievement tests [12], [13]. In addition, based on the results of PISA, the critical literacy scores of Indonesian students in total mostly fall below the standard, that is $<500$, with an average of $32 \%$ from all aspects evaluated including content $(29 \%)$, process $(34 \%)$, and context $(32 \%)$ [5].

Educators agree that science literacy should be taught from an early age. Science literacy should become part of primary education that serves a basis for developing other competencies required in higher levels of education [14]. The development of students' science literacy should not only be focused on empowering students to remember and apply scientific concepts in classroom learning, but also on how science is produced, how science works, how scientific discoveries and explorations are conducted in certain cultural and social contexts, and how science learning is designed [15]. Some factors that may influence the development of students' science literacy include optimized knowledge of scientific facts, concepts, and law, and changes in science instruction and theories [16].

Science literacy can be promoted through problem-based learning. Problem-based learning can encourage students to identify problems, construct the solutions, gather and analyze the data, support their arguments with evidence, and solve the problems [17]. One of the examples of learning models that are expected to improve students' science literacy is RICOSRE. The syntax of RICOSRE learning model which consists of reading, identifying the problem, constructing the solution, solving the problem, reviewing the solution, and extending the solution[18]has been proven effective in enhancing students' critical thinking skills [19], creative thinking skills, science process skills, and scientific argumentation skills. However, the potential of RICOSRE in improving students' science literacy requires further examination.
Based on the background of the problem, it is clear that a comprehensive study needs to be conducted to investigate the potential of RICOSRE learning model to enhance students' science literacy. The current study was an attempt to investigate: 1) an improvement in students' science literacy after implementing RICSORE syntax, and 2) the effect of RICOSRE learning model on students' science literacy in Protist classroom. The research hypothesis was formulated as "there was a difference between the students' science literacy pretest and post-test scores".

\section{METHODS}

\subsection{Design of the Study}

This study constituted part of the previous research on RICOSRE. A mixed-methods concurrent embedded design was employed in this study, where the quantitative (QUAN) data served as the primary data, and the qualitative (QUAL) data served as the secondary data. This concurrent embedded or concurrent nested mixedmethods study was carried out by collecting the qualitative and quantitative data simultaneously using different instruments[20]. To measure the participants' science literacy, a rubric from PISA was adapted [5]. Meanwhile, for a deeper understanding of the answer to the research problem, the QUAN data were supported by the QUAL data [21]. The design of the current study was presented in Figure 1 .

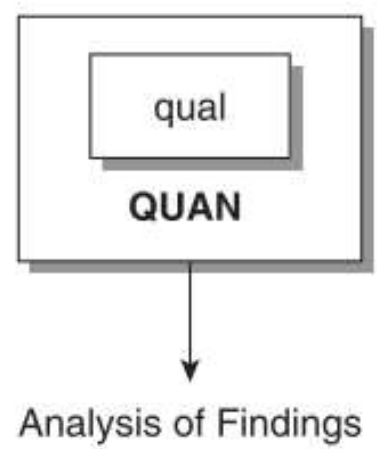

Figure 1. Concurrent Embedded Design with Prominence in QUAN

\subsection{The subject of the Study}

The subject of the study consisted of undergraduate students from Protist offering $\mathrm{C}$ registered in the even semester of 2018/2019 at the Department of Biology, FMIPA, UM. A purposive sampling method was used to select a heterogeneous group of 31 students.

\subsection{Quantitative Study}

The quantitative data were gathered using a pretest and a post-test in a one group pretest-post-test designed study. The data were analyzed using a t-test. Before conducting a t-test, data normality and homogeneity were examined. If the data were distributed normally and were homogeneous, 
a paired samples t-test was conducted, the data were not normal nor homogeneous, the Wilcoxon's test was performed.

\subsection{Qualitative Study}

To gather the qualitative data, observations on the students' performance in science literacy were conducted within ten weeks (two meetings per week). A descriptive analysis of the data would result in a description of the students' science literacy pattern.

\subsection{Instruments of the Study}

The instruments of this study were comprised of instruments for treatment and instruments for measurement. The instruments for treatment consisted of Semester Lesson Plan and RICOSRE-based Student Worksheet. The instruments for measurement consisted of essay tests to assess the participants' science literacy. The tests were conducted as a pretest, a mid-test, and a posttest. The students' test answers were scored using a rubric from the Programme for International Students Assessment or PISA[5].

The first indicator to be measured was able to explain a phenomenon scientifically. The descriptors of the first indicator were: (a) recalling and applying scientific knowledge appropriately, (b) identifying, using, and generalizing explanations from descriptions, (c) making a correct prediction and showing a clear and detailed relationship between the prediction with the phenomenon being explained, (d) formulating hypotheses based on predictions. The second indicator was able to design and evaluate a scientific investigation. The descriptors for this indicator included (a) identifying and exploring questions from previous scientific studies provided, (b) formulating the way to explore the questions using a detailed and appropriate scientific method, (c) conducting a scientific investigation based on the devised exploration plan, and (d) identifying the weaknesses and strengths of the plan and revising the plan if necessary. The third indicator of science literacy was able to interpret data and evidence scientifically. The descriptors of this indicator included (a) interpreting and communicating quantitative using proper and communicative technical language and drawing an appropriate inference, (b) organizing communicative tables or graphs based on the components of data, (c) identifying a breakthrough in technology and its relationship with science in detailed, and (d) explaining the impacts of technology breakthroughs on society from different perspectives.

\subsection{Strategies for Data Analysis}

The qualitative and quantitative data were identified and analyzed separately. The results of the analyses were combined and interpreted simultaneously according to the concurrent embedded design procedures to conclude the students' science literacy skills.

\section{RESULT AND DISCUSSION}

The result of the descriptive analysis showed that the students' average score improved gradually from the pretest to the post-test, from 35.89 to 56.27 . There was a $21.35 \%$ increase in the students' score from the pretest to the midtest (49.58) and a $13.27 \%$ increase from the mid-test to the post-test (56.27). Overall, the students' average score in science literacy had improved by $31.79 \%$ from the pretest to the post-test. Moreover, the result of the Wilcoxon's test indicated that only one student was experiencing a decrease in science literacy test scores, while the rest (30 students) showed an improvement in science literacy (Table 1).

Table 1. Signed Ranks Wilcoxon's Test

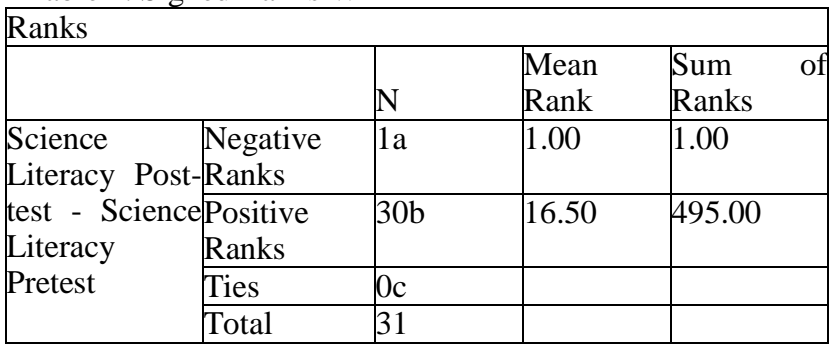

a. Science Literacy Post-test $<$ Science Literacy Pretest

b. Science Literacy Post-test $>$ Science Literacy Pretest

c. Science Literacy Post-test $=$ Science Literacy Pretest

Before testing the hypothesis, the normality of the pretest and post-test data was examined using the Shapiro-Wilk's test. The pretest data showed a significance level of $0.200>$ 0.05 . Hence the data were considered normal. On the other hand, the post-test data showed a significance level of $0.012<0.05$. Therefore the data were not distributed normally. Therefore, the Wilcoxon's test was conducted and the result was presented in Table 2 . The value of $\mathrm{Z}$ (4.842 ) with a significance level of $0.00<0.05$ presented in the table indicated that there was a difference between the students' pretest and post-test average scores.

Table 2. Statistical Analysis of the Students' Pretest and Post-test Scores

\begin{tabular}{|l|l|}
\hline $\mathrm{Z}$ & $-4.842 \mathrm{~b}$ \\
\hline Asymp. Sig. (2-tailed) & 0.000 \\
\hline
\end{tabular}

As mentioned earlier, the result of the qualitative data analysis would be used to support the result of the quantitative data analysis. The qualitative data analysis was performed by comparing the students' test answers with the indicators of science literacy. The result of the qualitative data analysis also showed that there was an improvement in the students' science literacy [5], indicated by a rise in numbers of descriptors mastered by the students. The students had shown a progressive development in explaining a phenomenon scientifically, designing and evaluating a scientific investigation, and interpreting data and evidence scientifically. The changing pattern in the students' answers indicated that the students' science literacy had continuously improved. The following excerpts contained two instances of the students' test answers. Student $\mathrm{R}$ showed an exemplary answer to the test 
questions, while Student $\mathrm{F}$ showed an answer lacking in science literacy.

Pretest Question: Eutrophication or algae blooming occurs due to an uncontrolled algae growth in an area of water. In January 2019, river eutrophication happened in Sydney, Australia, leading to the immediate death of thousands of fish within a few days. Eutrophication can also threaten the health of other aquatic organisms and humans.

a) Describe the entire process of eutrophication in freshwaters that is detrimental to the environment!

b) Provide solutions to the problems caused by eutrophication in rivers and lakes!

Student R's Answer: a) The number of algae in an unpolluted river is controllable (reproduction). However, rivers that are polluted by pesticides tend to contain excessive amounts of algae because some pesticides are composed of chemicals that can accelerate algae growth and reproduction. If the amount of algae in a river increases, the amount of O2in the water will decrease as it has been absorbed by the algae so that the fish and other aquatic organisms may die from lack of $\mathrm{O} 2$.

b) The dosages of pesticides and chemical fertilizers applied to cultivated rice fields should be adjusted to the level that can be absorbed completely by the plants so that no residual chemicals can pollute rivers nearby.

Student $\mathrm{R}$ was able to explain a phenomenon from a scientific point of view. The answer clearly showed that the student was able to recall and apply scientific knowledge appropriately (indicator 1.1), identify, use, and generalize explanations from descriptions (1.2), make an appropriate predication and show a clear and detailed relationship between the prediction with the phenomenon being explained (1.3), and formulate a hypothesis based on predictions (1.4). Unfortunately, the student had not exhibited the ability to design and evaluate a scientific investigation and interpret evidence scientifically.

Student F's answer: a) Eutrophication is a sudden increase in algae growthin a short period. Algae can grow rapidly with the help of other living things such as microbes. Therefore, algae can spread widely and quickly and create a symbiosis that benefits him.

b) Algae grow on humid surfaces, so cleaning ponds regularly can prevent the growth of algae.

Unlike students R's answer, student F's answer only displayed one indicator of science literacy, which is explaining a phenomenon scientifically (descriptor 1.1.: recalling and applying scientific knowledge appropriately).

The mid-test questions were not the same as the pretest and the post-test questions. However, these questions were constructed based on similar objectives.

Midtest Question: $\quad$ For more than a year, Florida's beautiful Gulf Coast visitorshad found dead fish stranded on the coastline. Red tide algae bloom affected the coastal communities from the Florida Panhandle to its southern tip. Karenia brevis algaebreed in concentrations higher than normal. For 16 months, many fish, dugongs, and dolphins were found dead due to this phenomenon. Based on the case above, answer the questions below

a) Why do you think that the red tide phenomenon appeared on Florida's beautiful Gulf Coast?

b) Why do you think that the red tide phenomenon could lead to the death of fish, dugongs, and dolphins?

Student R's Answer: a) In my opinion, the red tide phenomenon occurred on Florida's Beautiful Gulf Coast because the water contains a lot of nutrients and hot temperatures around the area can stimulate the photosynthetic process of algae, resulting in a big increase in algae growth (algae blooming). Karenia brevis, contains poisons that can attack nerves so fish can die because their gills are blocked by algae.

b) Karenia brevis, contains poisons that can attack nerves, so fish can die because their gills are blocked by algae. Fish can also suffer from oxygen deficiency due to an algal bloom.

The e xcerpt above showed that student $\mathrm{R}$ was able to explain a phenomenon scientifically (the first indicator of science literacy). When the studentdesigned and evaluated a scientific investigation, it was obvious that $\mathrm{s} / \mathrm{he}$ was able to meet descriptor (2.1) which is identifying questions explored from a scientific study, but was yet unable to do a scientific investigation based on exploration plans (2.2) nor interpret evidence scientifically (2.3).

Student F's Answer: a) Red tide occurring due to Pyrophyta algae blooming contains poisons that can lead to the death of fish/mollusks in the sea. Blooming may happen when nutrition or temperature in the area is at an optimum level.

b) Because red tide radiates poisonous light and destroys sea animals. Pyrophyta algae-devoured by plankton - plankton is devoured by fish and other sea animals - the sea animals are dead.

The first indicator that is explaining a phenomenon scientifically was depicted in Student F' answer a, indicated by the student's ability to recalling and applying scientific knowledge appropriately (1.1) and identifying, using, and generalizing explanations from descriptions. However, answer $b$ had not signified these descriptors.

The post-test and the pretest contained the same question items to assess the improvement of the students' science literacy. The post-test answers of student $R$ and student $F$ were presented as follows.

Student R's Answer: $\quad$ a) The algae population in the river in Sydney, Australia, was controlled at first. However, several factors such as water pollution that could change the water $p H$ into bases and the number of nutrients that increased from the residual disposal of household and agricultural waste provided an optimal environment for the algae to grow and develop very rapidly. As a result, the river was filled with a large number of algae, and the surface of the river was covered by algae. It was difficult for the sunlight to penetrate through this water so that many aquatic plants in the river could not survive. To survive, algae needs oxygen. The fish and algae in the river fought over oxygen, but because of the large amount of the algae, oxygen in the river reached a 
critical level; therefore, many aquatic organisms died from lack of oxygen.

b) By providing strict regulations regarding how to process factory waste or others. Or requires each factory to filter/treat waste before being discharged into rivers so that factors that affect algal growth cannot be found anymore in the waters. Consequently, algae will grow normally and not experience blooming, which can result in eutrophication.

The answer showed that the student had become more skilful in (1) identifying a phenomenon scientifically and (3) interpreting data and evidence scientifically, shown by his/her ability in (3.1) interpreting and communicating quantitative using proper and communicative technical language and drawing an appropriate inference and (3.3) identifying a breakthrough in technology and its relationship with science in detailed. However, the student's answer only showed one descriptor of the second indicator that is (2.1) identifying questions that have been explored from a scientific study.

Student F's Answer: a) Eutrophication can occur due to several factors. One of them is household waste, such as detergents. Algae blooming also occurs due to increased temperature, light intensity, and $\mathrm{pH}$ levels. Algae can bloom because it receives an excessive amount of nutrition so that it can grow very quickly.

b) First, there should be a strong policy established to control human population growth, because as the earth's population increases, the contribution of phosphate release to the water environment also increases. The government must also encourage entrepreneurs to avoid using phosphate in their detergent products. Likewise, it is also recommended not to put phosphate additives into food and beverage products. Besides that, agricultural sectors should be made aware of the harmful effects of applying an excessive amount of phosphate fertilizer, and the management of livestock sectors should be informed of their role in preventing more phosphate from being released into the water environment. People should be urged not to consume food and drinks containing excessive phosphate additives and not to throw waste into rivers.

Student $\mathrm{F}$ showed a significant improvement in science literacy, indicated in his ability in (1) explaining a phenomenon scientifically, (2) designing and evaluating a scientific investigation and (2.1) identifying questions explored from a scientific study, (3) interpreting data and evidence scientifically through (3.1) interpreting and communicating quantitative using proper and communicative technical language and drawing an appropriate inference, (3.3) identifying a breakthrough in technology and its relationship with science in detailed, and (3.4) explaining the impacts of technology breakthroughs on society from different perspectives.

From the research finding, it is known that students' psychomotor competence improves because of treatment given in experimental class. The average score in of students' psychomotor competence in experimental class is higher than in control class. In experimental class, the average score is 85.93 ; while, in control class, it is 81.98 . So, it means that the difference is 3.95 . It shows that the effect of provided treatment can improve students' psychomotor competence. Based on the result of hypothesis testing, it is known that there is a significant different between average score in experimental class and average score in control class, with sig. value is 0.010 , which means that $\mathrm{HO}$ is rejected and $\mathrm{H} 1$ is accepted (there is a significant difference between experimental class and control class).

The example non example method is a learning method which uses picture as media in delivering learning materials. Pictures as learning media should be flexible, in which it can overcome space, time, and sense limitation [7]. Furthermore, the pictures which are chosen as learning media should be clear and able to explain or represent the learned materials [8].

The direct observation as the result of observation, is also a form of example non example method implementation because observation result is analyzable data. The example non example method is not only limited on pictures, but also on visualized observation result. It can also be sources in example non example method implementation. The example non example method makes students more critical in analyzing pictures. Students can have chance to give opinion and understand learning materials by giving examples in from of pictures [9].

According to [9], through example non example method, students are involved to a) enlarge their understanding to be deeper and more complex, b) through discovery process, it encourages students to build concepts progressively through direct observation related to examples. Learning process can use relevant example or case related to learned basic competence [10].

In implementing practice of BC 3.6 (Organization of Living System), students are exposed to data in forms of pictures and tables observed by them during practice process. Result of observation can support students' comprehension by making learning materials more concrete [11]. In addition, through pictures and observation result, students can be facilitated to do discovery learning activity [9]. [12] also explain that this method is appropriate to be collaborated with discovery model to improve students' psychomotor competence. Discovery activity is an activity that makes students active in finding knowledge so that the demand of the 2013 curriculum can be completed well. It is in line with [13] also states that through example analysis activity, students can be facilitated to prove knowledge. Students' activity can encourage participation learning [14].

In learning process, students are more motivated to ask questions related to the provided pictures. Pictures can attract students' attention. Asking question is an indicator in presentation skills. In other words, improvement of students' ability in asking question also affects students' psychomotor competence. It is in line with $[3,4]$ also assert that example non example method is effective in improving students' activities in learning. 


\section{CONCLUSION}

The conclusion of the research is example non-example method has significant effect on students' psychomotor competence in organization of living system learning materials. In selecting learning method, it should be considered the suitability of learning materials and learning method. In addition, it should be considered students' learning styles intelligence so that learning objectives can be achieved well. For Biology teachers, it is suggested to implement example non-example method as an effort to improve students' psychomotor competence.

\section{REFERENCES}

[1] Lufri, Fitri, R., dan Yogica, R. 2018.

"Development of Learning Models Based on Problem Solving and Meaningful Learning Standards by Expert Validity for Animal Development Course". In IOP Conference Series: Materials Science and Engineering, 335(1), p. 012094. IOP Publishing.

[2] Lufri, Sudirman, S., dan Rahmi, S. 2016. "Mengembangkan Skill Mengajar (Teaching Skill) Mahasiswa Calon Guru Menggunakan Multy Strategies". Ta'dib, 15(1).

[3] Setyaningsih, Y., Margereta, R., Bambang, P. 2013. "Penerapan Metode Example Non Example dalam Pembelajaran Keanekaragaman Hewan di SMPN 2 Tengaran Kabupaten Semarang”. Journal of Biology Education, 2(2): 156-164.

[4] Suryani, K., Rusdi, Syafri, M. 2016. "Penerapan Metode Examples Non Examples untuk Meningkatkan Akivitas dan Hasil Belajar Matematika Siswa Kelas VII SMP AlKarim Kota Bengkulu”. Thesis. Bengkulu: Universitas Bengkulu.

Zainal, A. 2011. Micro Teaching. Jakarta: Rajawali Press.

[6] Briggs, C. L. 2001. "Discovery Learning, Cognitive Psychology of". Elsevier: International Encyclopedia of the Social Science, 3736-3739.

[7] Andromeda, A., Lufri, Festiyed, Allizar, E., Iryani, I, Guspatni, G., Fitri, L. 2018. "Validity and Practicality of Experiment Integrated Guided Inquiry-Based Module on Topic of Colloidal Chemistry for Senior High School Learning". In IOP Conference Series: Materials Science and Engineering, 335(1), p. 012094. IOP Publishing.
[8] Oktarina, K., Lufri, dan Chatri, M. 2018 "Validity of Learning Module Natural Sciences Oriented Constructivism with the Contain of Character Education for Students of Class VIII at Junior High School". In IOP Conference Series: Materials Science and Engineering, 335(1), p. 012094. IOP Publishing.

[9] Huda, H. 2014. Model-model Pengajaran dan Pembelajaran. Yogyakarta: Pusta Pelajar.

[10] Taniredja, T., Efi, M. F., Sri, H. 2014. Modelmodel Pembelajaran Inovatif dan Efektif. Bandung: Alfabeta.

[11] Takacs, Z. K., Adriana, G. B. 2017. "How Pictures in Picture Storybooks Support Young Children's Story Comprehension: An EyeTracking Experiment". Elsevier: Journal of Experimental Child Psychology, 174: 1-12.

[12] Amrianto dan Lufri. 2019. "Effect of Example Non Example Method Implementation in Scientific Approach and Discovery Learning Model on VII Garde Students' Affective Competence in Learning Natural Science". International Journal of Advanced Research (IJAR), 7(3), 66-70.

[13] Knuth, E., Orit, Z., Amy., E. 2017. "The Role and Use of Examples in Learning to Prove". Elsevier: Journal of Mathematical Behavior, $1-7$.

[14] Yerimadesi, Bayharti, Jannah, S. M., Lufri, Festiyed, dan Kiram, Y. 2018. "Validity and Practicality of Acid Base Module Based on Guided Discovery Learning for Senior High School". In IOP Conference Series: Materials Science and Engineering, 335(1), p. 012094. IOP Publishing. 